\title{
Bibliography
}

Aldana Reyes, Xavier. Body Gothic: Corporeal Transgression in Contemporary Literature and Horror Film. Cardiff: University of Wales Press, 2014.

Aldana Reyes, Xavier. 'Fear, Divided: Terror and Horror - The Two Sides of the Gothic Coin.' Emagazine, 68 (2015), pp. 49-52.

Aldiss, Brian. Frankenstein Unbound. Thirsk: House of Stratus, 1975.

Allmer, Patricia. "Breaking the Surface of the Real": The Discourses of Commodity in Clive Barker's Hellraiser Narratives.' Space, Haunting, Discourse. Eds. Maria Holmgren Troy and Elisabeth Wennö. Newcastle: Cambridge Scholars Publishing, 2008, pp. 14-24.

Ancuta, Katarzyna. 'Pain into Pleasure or the Horror of Creation: Notes on Reading Clive Barker's The Great and Secret Show'. (Aesth)etics of Interpretation: Essays in Cultural Practice, Eds. Wojcicch Kalaga and Tadeusz Rachwał. Katowice, Poland: Wydawnictwo Uniwersytetu Śląskiego, 2000, pp. 159-70.

Anderson, Tonya. 'Still Kissing Their Posters Goodnight: Female Fandom and Politics of Popular Music.' Participations: Journal of Audience and Reception Studies. Vol. 9:2 (2012), pp. 239-64.

Artaud, Antonin. The Theatre and its Double. Trans. Victor Corti, Montreuil, London and New York: Calder, 1993.

Artaud, Antonin. 'No More Masterpieces', Trans. Victor Corti, Montreuil, London and New York: Calder, 1993, pp. 56-63.

Artaud, Antonin. 'Theatre and the Plague,' The Theatre and its Double. Trans. Victor Corti, Montreuil, London and New York: Calder, 1993, pp. 7-22.

Babouris, Bill. 'Addicted to Creativity' Samhain, Issue 70 (November 1998).

Badley, Linda. Writing Horror and the Body: The Fiction of Stephen King, Clive Barker, and Anne Rice. Westport, CT: Greenwood Press, 1996.

Baker, Houston A. Jr. Blues, Ideology, and Afro-American Literature: A Vernacular Theory. Chicago: University of Chicago Press, 1991.

Baker, Houston A. Jr. Workings of the Spirit: The Poetics of Afro-American Women's Writing. Chicago: University of Chicago Press, 1984.

Balides, Constance. 'Jurassic Post-Fordism: Tall Tales of Economics in the Theme Park.' Screen. Vol. 41:2 (2000), pp. 139-60. 
Bamford, Paul. 'Clive Barker.' Contemporary North American Film Directors: A Wallflower Critical Guide. Eds. Yoram Allon, Del Cullen, and Hannah Patterson. London and New York: Wallflower Press, 2002, pp. 37-8.

Barbieri, Suzanne J. Clive Barker: Mythmaker for the Millennium. Stockport: British Fantasy Society, 1994.

Barker, Clive. Abarat. New York: HarperCollins, 2002.

Barker, Clive. Abarat: Absolute Midnight. New York, HarperCollins, 2011.

Barker, Clive. Abarat: Days of Magic, Nights of War. New York: HarperCollins, 2004.

Barker, Clive. Cabal. London: Fontana, 1988.

Barker, Clive. Clive Barker's Books of Blood, Omnibus Edition, Volumes 1-3. London: Sphere, 1988; and London: Warner, 1998.

Barker, Clive. Clive Barker's Books of Blood, Omnibus Edition, Volumes 4-6. London: Sphere, 1988; and London: Warner 1998.

Barker, Clive. Coldheart Canyon. London: HarperCollins, 2001.

Barker, Clive. 'Christopher Marlowe's The Tragical History of Doctor Faustus.' Clive Barker's Shadows in Eden. Ed. Stephen Jones. Lancaster, PA: Underwood Miller, 1991, pp. 111-14.

Barker, Clive. The Damnation Game. London: Sphere, 1985.

Barker, Clive. Everville. London: HarperCollins, 1995.

Barker, Clive. Galilee. London: HarperCollins, 1998.

Barker, Clive. The Great and Secret Show. London: HarperCollins, 1989.

Barker, Clive. The Hellbound Heart. [1986]. London: Dark Harvest. HarperCollins, 1991.

Barker, Clive. Imajica. New York: HarperCollins, 1991.

Barker, Clive. In Conversation with Sorcha Ní Fhlainn, a special panel presented as part of the Clive Barker: Dark Imaginer conference, 14 July, 2011, Trinity College, Dublin.

Barker, Clive. Interview with Nick Hasted, Creature, No. 5 (1986).

Barker, Clive. Interview with Richard Lupoff, Richard Wolinsky, and Lawrence Davidson. 'A Talk with the King.' Stephen King and Clive Barker: The Illustrated Guide to the Masters of the Macabre II. Ed. James Van Hise. Las Vegas, NV: Pioneer Books, 1992, pp. 79-95.

Barker, Clive. 'An Introduction: Private Legends.' The Essential Clive Barker. London: HarperCollins, 1999, pp. 1-27.

Barker, Clive. Mister B. Gone. London: HarperVoyager, 2007.

Barker, Clive. 'One Flesh Exhibition', Clive Barker: The Painter, the Creature, and the Father of Lies. Eds. Phil and Sarah Stokes. Northborough, MA: Earthling Publications, 2011, p. 219.

Barker, Clive. Public interview and Q\&A at the Irish Film Institute. 13 July 2011. Clive Barker: Dark Imaginer conference, Trinity College, Dublin. Public Event.

Barker, Clive. 'Ramsay Campbell: An Appreciation.' 1986 World Fantasy Convention Programme.

Barker, Clive. Sacrament. London: HarperCollins, 1996.

Barker, Clive. The Scarlet Gospels. London: Macmillan, 2015.

Barker, Clive. The Thief of Always. London: HarperCollins, 1992.

Barker, Clive. Tortured Souls: Six Destinies, Tempe, AZ: Todd McFarlane, 2001. 
Barker, Clive. Weaveworld. London: Collins, 1987.

Barker, Clive and Stephen Jones. Clive Barker's A-Z of Horror. London: BBC Books, 1997.

Barker, Paul. The Freedoms of Suburbia. London: Frances Lincoln, 2009.

Bassett, Jonathan F. 'Death and Magic in Clive Barker's Lord of Illusions: A Terror Management Perspective.' Studies in Popular Culture. Vol. 32:1, Fall 2009, pp. 67-78.

Beeler, Michael. 'Clive Barker: Horror Visionary.' Cinefantastique. Vol. $26: 3$ (1995), pp. 16-22.

Benshoff, Harry M. Monsters in the Closet: Homosexuality and the Horror Film, Manchester and New York: Manchester University Press, 1997.

Benshoff, Harry M. 'The Monster and the Homosexual.' Horror: The Film Reader. Ed. Mark Jancovich. London: Routledge, 2002, pp. 91-102.

Benshoff, Harry M. "Way Too Gay To Be Ignored”: The Production and Reception of Queer Horror Cinema in the Twenty-First Century.' Speaking of Monsters: A Teratological Anthology. Eds. Caroline Joan S. Picart and John Edgar Browning. Basingstoke: Palgrave Macmillan, 2012, pp. 131-44.

Benshoff, Harry M. and Sean Griffin. Queer Images: A History of Gay and Lesbian Film in America. Oxford: Rowman \& Littlefield, 2006.

Blake, Linnie. The Wounds of Nations: Horror Cinema, Historical Trauma and National Identity. Manchester and New York: Manchester University Press, 2008.

Blake, William. 'London.' William Blake: The Complete Illuminated Books. Ed. David Bindman. London: Thames \& Hudson, 2001.

Blumenfeld, Warren J. Homophobia: How We All Pay the Price. Boston: Beacon Press, 1992.

Bradbury, Dominic. The Iconic House: Architectural Masterworks since 1900. London: Thames \& Hudson, 2009.

Brook-Rose, Christine. A Rhetoric of the Unreal: Studies in Narrative and Structure, Especially of the Fantastic. Cambridge: Cambridge University Press, 1981.

Brosnan, John. 'Terror Tactics.' Clive Barker's Shadows in Eden. Ed. Stephen Jones. Lancaster, PA: Underwood-Miller, 1991, p. 89-93.

Brown, Derren. Tricks of the Mind. London: Channel Four Books, 2006.

Burke, Edmund. A Philosophical Enquiry into the Origin of Our Ideas of the Sublime and Beautiful. Ed. with an Introduction by Adam Phillips. Oxford: Oxford University Press, 1990.

Burns, Craig William. 'It's That Time of the Month: Representations of the Goddess in the Work of Clive Barker' Journal of Popular Culture. Vol. 27:3 (1993). pp. 35-40.

Cardwell, Sarah. 'Adaptation Studies Revisited: Purposes, Perspectives, and Inspiration.' The Literature/Film Reader: Issues of Adaptations. Eds. James M. Welsh and Peter Lev. Lanham, MA: The Scarecrow Press, 2007, pp. 51-63.

Carroll, Nöel. The Philosophy of Horror or Paradoxes of The Heart. London: Routledge, 1990.

Carter, Angela. The Sadeian Woman: An Exercise in Cultural History. London: Virago, 1979.

Cherry, Brigid. 'Beyond "Suspiria”: The Place of European Cinema in the Fan Canon.' European Nightmares: European Horror Cinema Since 1945. Eds. Patricia Allmer, Emily Brick, and David Huxley. London: Wallflower Press, 2012, pp. 25-34. 
Cherry, Brigid. 'Broken Homes, Tortured Flesh: Hellraiser and the Feminine Aesthetic of Horror Cinema.' Film International. Vol. 3:17 (2005), pp. 10-21.

Cherry, Brigid. 'Imperfect Geometry: Identity and Culture in Clive Barker's "The Forbidden” and Bernard Rose's Candyman.' Monstrous Adaptations: Generic and Thematic Mutations in Horror Film. Eds. Richard. J. Hand and Jay McRoy. Manchester: Manchester University Press, 2007, pp. 48-63.

Cherry, Brigid. 'Subcultural Tastes, Genre Boundaries and Fan Canons.' The Shifting Definitions of Genre: Essays on Labelling Films, Television Shows and Media. Eds. Mark Jancovich and Lincoln Geraghty. Jefferson, NC: McFarland, 2007, pp. 201-15. Cherry, Brigid. 'Refusing to Refuse to Look: Female Viewers of the Horror Film.' Identifying Hollywood Audiences. Eds. Richard Maltby and Mervyn Stokes. London: BFI, 1999, pp. 187-203.

Cherry, Brigid and Brian Robb. 'Birth of the Nightbreed.' Starburst. Vol. 11:11 (1989). Cherry, Brigid, Charles O’Brien, and Nikolaus Pevsner. The Buildings of England: London 5: East. New Haven: Yale University Press, 2005.

Chibnall, Steve and Julian Petley (eds). British Horror Cinema. London: Routledge, 2001.

Coleman, Alice and the Design Disadvantagement Team of the Land Research Unit, King's College London. Utopia on Trial: Vision and Reality in Planned Housing. London: Shipman, 1985.

Conrich, Ian. 'The Friday the 13th Films and the Cultural Function of a Modern Grand Guignol.' Horror Zone: The Cultural Experience of Contemporary Horror Cinema. Ed. Ian Conrich. London: IB Tauris, 2010, pp. 173-88.

Coyle, William. 'Introduction: The Nature of Fantasy'. Aspects of Fantasy: Selected Essays From the Second International Conference on the Fantastic in Literature and Film. Ed. William Coyle. Westport: Greenwood, 1986, pp. 1-3.

Daumann, Christian. Wonderlands in Flesh and Blood: Gender, the Body, Its Boundaries and Their Transgression in Clive Barker's Imajica. München, Germany: AVM, 2009.

De Quincey, Thomas. 'On the Knocking at the Gate in Macbeth.' On Murder. Ed. Robert Morrison. Oxford: Oxford University Press, 2006, pp. 3-7.

Deleuze, Gilles. Cinema 1: The Movement-Image. [1983]. Trans. Hugh Tomlinson and Barbara Habberjam. London and New York: Continuum International Publishing Group, 2005.

Denton, Eric Hadley. 'Johann Wolfgang von Goethe.' The Handbook to Gothic Literature. Ed. Marie Mulvey Roberts. New York: New York University Press, 1998, pp. 70-2.

Doty, Alexander. Flaming Classics: Queering the Horror Canon. London: Routledge, 2000.

Dufour, Éric. Le Cinéma d'horreur et ses figures. Paris: Presses universitaires de France, 2006.

Dunnett, James. 'A Terrible Beauty ... ’ Ernö Goldfinger: Works I. Eds. James Dunnett and Gavin Stamp. London: Architectural Association, 1983, p. 7.

Dunnet, James and Gavin Stamp (eds). Ernö Goldfinger: Works I. London: Architectural Association, 1983.

Dyer, Richard. Culture of Queers. London: Routledge, 2001.

Elwall, Robert. Building a Better Tomorrow: Architecture in Britain in the 1950s. Chichester: Wiley-Academy, 2000.

Fiske, John. Television Culture. London: Routledge, 1987. 
Foucault, Michel. 'What is An Author?' [1969.] Essential Works of Foucault 1954-1984 Vol. 2: Aesthetics. Ed. J.D. Faubion. London: Penguin Books, 1994.

Fowles, John. The Magus. Suffolk: Triad Granada, 1966.

Fox, Robert Elliot. Master of the Drum: Black Lit/oratures Across the Continuum. Westport: Greenwood, 1995.

Freeland, Cynthia. 'Feminist Frameworks for Horror Films.' Film Theory and Criticism. Eds. Leo Braudy and Marshall Cohen. Oxford: Oxford University Press, 2004.

Freeland, Cynthia. The Naked and the Undead: Evil and the Appeal of Horror. Boulder: Westview Press, 2000.

Gates, Henry Louis, Jr. The Signifying Monkey: A Theory of African-American Literary Criticism. New York: Oxford University Press, 1988.

Gilroy, Paul. The Black Atlantic: Modernity and Double Consciousness. Cambridge, Mass: Harvard University Press, 1993.

Gochros, Jean S. 'Homosexuality and Heterosexual Marriage.' Homophobia: How We All Pay the Price. Ed. Warren J. Blumenfeld. Boston: Beacon Press, 1992.

Grainge, Paul. Brand Hollywood: Selling Entertainment in a Global Media Age. London: Routledge, 2007.

Grant, Barry Keith (ed.). The Dread of Difference: Gender and the Horror Film. Austin: University of Texas Press, 1996.

Grant, Catherine. 'Auteur machines? Auteurism and the DVD.' Film and Television After DVD. Eds. James Bennett and Tom Brown. London: Routledge, 2008, pp. 101-15.

Halberstam, Judith. Skin Shows: Gothic Horror and the Technology of Monsters. Durham and London: Duke University Press, 1995.

Halley, Janet and Andrew Parker. After Sex? On Writing since Queer Theory. London: Duke University Press, 2011.

Hanley, Lynsey. Estates: An Intimate History. London: Granta, 2007.

Hansom, Dick. 'To Hell and Back.' Speakeasy. Issue: 102 (September 1989). Quoted in Clive Barker's Shadows in Eden. Ed. Stephen Jones. Lancaster, PA: Underwood-Miller, 1991, p. 359.

Hendershot, Heather. 'Masters of Horror: TV Auteurism and the Progressive Potential of a Disreputable Genre.' Flow TV: Television in the Age of Media Convergence. Eds. Michael Kackman, Marie Binfield, Matthew Thomas Payne, Allison Perlman, and Bryan Sebok. New York: Routledge, 2011, pp. 144-63.

Higson, Andrew. Film England: Culturally English Filmmaking Since the 1990s. London: IB Tauris, 2011.

Hogle, Jerrold E. 'Introduction: The Gothic in Western Culture.' The Cambridge Companion to Gothic Fiction. Ed. Jerold E. Hogle. Cambridge: Cambridge University Press, 2002, pp. 1-20.

Hogle, Jerrold E. (ed.) The Cambridge Companion to Gothic Fiction. Cambridge: Cambridge University Press, 2002.

Holmberg, Carl B. Sexualities and Popular Culture. Ohio: Bowling Green State University, 1998.

Hoppenstand, Gary. Clive Barker's Short Stories: Imagination as Metaphor in the Books of Blood and Other Works. Jefferson, NC and London: McFarland, 1994. 
Horkheimer, Max and Theodor W. Adorno. Dialectic of Enlightenment: Philosophical Fragments. Ed. Gunzelin Schmid Noerr. Trans. Edmund Jephcott. Stanford, CA: Stanford University Press, 2002.

Hill, Annette. Paranormal Media: Audiences, Spirits and Magic in Popular Culture. London and New York: Routledge, 2011.

Hills, Matt. 'An Event-Based Definition of Art-Horror.' Dark Thoughts: Philosophic Reflections on Cinematic Horror. Eds. Steven Jay Schneider and Daniel Shaw. Lanham, MD: Scarecrow Press, 2003, pp. 138-57.

Hollows, Joanna. 'The Masculinity of Cult.' Defining Cult Movies: The Cultural Politics of Oppositional Taste. Ed. Mark Jancovich. Manchester: Manchester University Press, 2003, pp. 35-53.

Hume, Kathryn. Fantasy and Mimesis: Responses to Reality in Western Literature. New York: Methuen, 1984.

Irwin, William. R. The Game of the Impossible: A Rhetoric of Fantasy. Urbana: University of Illinois Press, 1976.

Jackson, Rosemary. Fantasy: The Literature of Subversion. London: Methuen, 1981.

Jackson, Stevi. 'Women and Heterosexual Love: Complicity, Resistance and Change.' Sex, Self and Society: The Social Context of Sexuality. Ed. Tracey L. Steele. Belmont, CA: Wadsworth, 2005.

Jaggose, Annamarie. Queer Theory: An Introduction. Melbourne: Melbourne University Press, 1996.

Jenkins, Henry. Convergence Culture: Where Old and New Media Collide. New York: New York University Press, 2008.

Jones, Stephen. 'Clive Barker: Anarchic Prince of Horror.' Knave. Vol. 15:5 (1987).

Joshi, S.T. The Modern Weird Tale. Jefferson, NC: McFarland, 1994.

Kane, Paul. The Hellraiser Films and Their Legacy. Jefferson, NC: McFarland, 2006.

Kaveney, Roz. 'Dark Fantasy and Paranormal Romance.' The Cambridge Companion to Fantasy Literature. Eds. Edward James and Farah Mendlesohn. Cambridge: Cambridge University Press, 2012, pp. 214-23.

Kilday, Gregg. 'Out in America. Film: Clive Barker Raises Hell.' Out (March 1995) p.

14. Quoted in Harry M. Benshoff. Monsters in the Closet: Homosexuality and the Horror Film. Manchester: Manchester University Press, 1997.

King, Geoff. Spectacular Narratives: Hollywood in the Age of the Blockbuster. London: IB Tauris, 2000.

King, Stephen. Danse Macabre. [1982]. London: Warner, 1993.

Kynaston, David. Austerity Britain, 1945-51. London: Bloomsbury, 2007.

Kynaston, David. Family Britain, 1951-57. London: Bloomsbury, 2009.

Kynaston, David. Modernity Britain: A Shake of the Dice, 1959-62. London: Bloomsbury, 2014.

Kynaston, David. Modernity Britain: Opening the Box, 1957-59. London: Bloomsbury, 2013.

Laity, K.A. 'Imagineer: Clive Barker's Queering of the Conservative Bent of Horror Literature.' Horrifying Sex: Essays on Sexual Difference in Gothic Litearture. Ed. Ruth Bienstock Anolik. Jefferson, NC: McFarland, 2007, pp. 248-58. 
Landon, Brooks. The Aesthetics of Ambivalence: Rethinking Science Fiction Film in the Age of Electronic (Re)Production, Westport, Connecticut, and London: Greenwood Press, 1992.

Latham, Rob. 'Phallic Mothers and Monster Queers.' Science Fiction Studies. Vol. 25:1 (1998), pp. 87-101.

Leese, Peter. Britain Since 1945. Hampshire: Palgrave Macmillan, 2006.

Letwin, Shirley Robin. The Anatomy of Thatcherism. New Brunswick and London: Transaction Publishers, 1993.

Levi, Jeffrey. 'Homophobia and the AIDS Public Policy.' Homophobia: How We All Pay the Price. Ed. Warren J. Blumenfeld. Boston: Beacon Press, 1992.

Lovecraft, H.P. 'Supernatural Horror in Literature.' H.P. Lovecraft, Tales: A Miscellany of the Macabre. Ed. Stephen Jones. London: Gollancz, 2011, pp. 423-92.

Lury, Celia. Brands: The Logos of the Global Economy. London: Routledge, 2004.

MacCormack, Patricia. Cinesexuality, Aldershot and Burlington: Ashgate Publishing, 2008.

Mains, Johnny. Lest You Should Suffer Nightmares: A Biography of Herbert Van Thal. Bargoed: Screaming Dreams, 2011.

Manlove, Colin N. 'On the Nature of Fantasy.' The Aesthetics of Fantasy Literature and Art. Ed. Roger C. Schlobin. Indiana: University of Notre Dame Press, 1982, pp. 16-35.

Marlowe, Christopher. Doctor Faustus and Other Plays. [1592]. Eds. David Bevington and Eric Rasmussen. Oxford: Oxford University Press, 1995.

Marquand, David. 'Moralists and Hedonists.' The Ideas that Shaped Post-War Britain. Eds. David Marquand and Anthony Seldon. London: Fontana Press, 1996, pp. 5-28.

McCauley, Kirby (ed.) Dark Forces: New Stories of Suspense and the Supernatural. New York: Viking, 1980.

McDonagh, Maitland. 'A Kind of Magic.' The Dark Side. No. 45. April/May 1995.

McLaren, Angus. Twentieth-Century Sexuality. Oxford: Blackwell Publishers, 1999.

McRoy, Jay. 'There are No Limits: Splatterpunk, Clive Barker, and the Body In-Extremis.' Paradoxa. No. 17 (2002), pp. 130-50.

McSmith, Andy. No Such Thing as Society: A History of Britain in the 1980s. London: Constable, 2011.

Miéville, China. Kraken. London: Macmillan, 2010.

Miéville, China and Joan Gordon. 'Reveling in Genre: An Interview with China Miéville.' [sic] Science Fiction Studies. Vol. 30:3. (November 2003), pp. 355-73.

Moten, Fred. In the Break: The Aesthetics of the Black Radical Tradition. Minneapolis: University of Minnesota Press, 2003.

Morgan, Kenneth O. Britain Since 1945. Oxford: Oxford University Press, 2001.

Nama, Adilifu. Black Space: Imagining Race in Science Fiction Film. Austin: University of Texas Press, 2008.

Ndalianis, Angela. 'Architectures of the Senses: Neo-Baroque Entertainment Spectacles.' Rethinking Media Change: The Aesthetics of Transition. Eds. David Thorburn and Henry Jenkins. Cambridge, Mass: MIT Press, 2003, pp. 355-74.

Ndalianis, Angela. 'Dark Rides, Hybrid Machines and the Horror Experience.' Horror Zone: The Cultural Experience of Contemporary Horror Cinema. Ed. Ian Conrich. London: IB Tauris, 2010, pp. 11-26.

Neale, Steve. 'Masculinity as Spectacle.' The Sexual Subject: A Screen Reading in Sexuality. London: Routledge, 1992. 
Niles, Steve and Les Edwards. Clive Barker's Dread. London: Eclipse Books, 1993.

Penny, Laurie. Cybersexism: Sex, Gender and Power on the Internet. London: Bloomsbury, 2013.

Powell, Anna. Deleuze and the Horror Film. Edinburgh: Edinburgh University Press, 2005.

Power, Anne. Estates on the Edge: The Social Consequences of Mass Housing in Europe. Basingstoke: Macmillan, 1997.

Powers, Alan. Britain, 'Modern Architectures in History' series. London: Reaktion, 2007.

Radcliffe, Ann. 'The Supernatural in Poetry.' Gothic Documents: A Sourcebook 1700-1820.

Eds. E.J. Clery and Robert Miles. Manchester: Manchester University Press, 2000, pp. 163-72.

Riddell, Peter. The Thatcher Era and Its Legacy. Oxford: Basil Blackwell, 1991.

Rodley, Chris (ed.) Cronenberg on Cronenberg. London: Faber and Faber, 1997.

Rosen, Andrew. The Transformation of British Life 1950-2000. Manchester: Manchester University Press, 2003.

Russo, Vito. The Celluloid Closet: Homosexuality in the Movies. Revised Edition. New York: Harper \& Row, 1987.

Ryall, Chris and Gabriel Rodriguez. Complete Clive Barker's Great and Secret Show. San Diego: Idea \& Design Works, 2007.

Sabouraud, Frédéric. L'Adaptation: Le Cinema a tant besoin d'histoires. Paris: Cahiers du cinéma/Scérén-CNDP. Les Petits Cahiers, 2006.

Sandbrook, Dominic. Never Had It So Good: A History of Britain from Suez to the Beatles. London: Abacus, 2006.

Sandbrook, Dominic. Seasons in the Sun: The Battle for Britain, 1974-1979. London: Allen Lane, 2012.

Sandbrook, Dominic. State of Emergency: The Way We Were: Britain, 1970-1974. London: Allen Lane, 2010.

Sandbrook, Dominic. White Heat: A History of Britain in the Swinging Sixties. London: Abacus, 2007.

Schleir, Curt. 'The Future of Horror is Here: His Name is Clive Barker'. Inside Books. (November 1988).

Schneider, Steven Jay. 'Toward an Aesthetics of Cinematic Horror.' The Horror Film. Ed. Stephen Prince. Piscataway, NJ: Rutgers University Press, 2004, pp. 131-49.

Sedgwick, Eve. Epistemology of the Closet. Los Angeles: University of California Press, 1990.

Sharett, Christopher. 'The Horror Film in Neoconservative Culture.' The Dread of Difference: Gender and the Horror Film. Ed. Barry Keith Grant, Austin: University of Texas Press, 1996, pp. 253-78.

Stewart, Graham. Bang! A History of Britain in the 1980s. London: Atlantic, 2013.

Stregnell, Heidi. Dissecting Stephen King: From the Gothic to Literary Naturalism. Madison: University of Wisconsin Press, 2006.

Swinfen, Ann. In Defense of Fantasy: A Study of the Genre in English and American Literature Since 1945. London: Routledge, 1984.

Todorov, Tzvetan. The Fantastic: A Structural Approach to a Literary Genre. Trans. Richard Howard. London: Case Western Reserve University Press, 1973.

Turner, Alwyn W. Rejoice! Rejoice! Britain in the 1980s. London: Aurum, 2010.

Van Thal, Herbert (ed.) The Pan Book of Horror Stories, 30 vols. London: Pan, 1959-1989. 
Vandermeer, Ann and Jeff Vandermeer (eds). The New Weird. Tachyon: San Francisco, 2008.

Waddington, Mark. 'Leroy Cooper: The Toxteth Riots Were a Wake-Up Call and Did Some Good.' Liverpool Echo, 4 July 2011.

Wagner, Chuck and Fred Burke, Denys Cowan and Michael Davis. 'Clive Barker's The Midnight Meat Train.' Tapping the Vein. Vol. 3. London: Eclipse Books, 1990.

Warburton, Nigel. Ernö Goldfinger: The Life of an Architect. London: Routledge, 2005.

Wells, Paul. 'On the Side of the Demons: Clive Barker's Pleasures and Pains. Interviews with Clive Barker and Doug Bradley'. British Horror Cinema. Eds. Steve Chibnall and Julian Petley. London: Routledge, 2002, pp. 172-82.

Wells, Paul. The Horror Genre: From Beelzebub to Blair Witch. London: Wallflower, 2000.

Wexman, Virginia Wright. Creating the Couple: Love, Marriage, and Hollywood Performance. Princeton: Princeton University Press, 1993.

Wiater, Stanley. 'Horror in Print: Clive Barker.' Clive Barker's Shadows in Eden. Ed. Stephen Jones, Lancaster, PA: Underwood-Miller, 1991, pp. 191-8.

Williams, Linda. 'When the Woman Looks.' Horror: The Film Reader. Ed. Mark Jancovich. London: Routledge, 2002.

Winter, Douglas, E. Clive Barker: The Dark Fantastic. London: HarperCollins, 2001.

Wood, Robin. 'An Introduction to the American Horror Film.' Planks of Reason: Essays on the Horror Film. Ed. Barry Keith Grant. Metuchen, NJ: Scarecrow Press, 2004, pp. 164-200.

Zipes, Jack. 'Why Fantasy Matters Too Much.' The Journal of Aesthetic Education. Vol. 43:2 (2009), pp. 79-91.

Žižek, Slavoj. 'The Specter of Ideology.' The Žižek Reader. Eds. Elizabeth Wright and Edmund Wright. Oxford: Blackwell, 1999, pp. 53-86.

\section{Film and television references}

Bill and Ted's Excellent Adventure. Dir. Stephen Herek, 1989.

Book of Blood. Dir. John Harrison, 2009.

Candyman. Dir. Bernard Rose, 1992.

Child's Play. Dir. Todd Holland, 1988.

Clive Barker.' The South Bank Show. BBC, 1994.

Clive Barker: The Man Behind the Myth. Dir. Sam Hurwitz, 2007.

Clive Barker's A-Z of Horror. BBC. Six part series, 1997-98.

Dread. Dir. Anthony DiBlasi, 2009.

F for Fake. Dir. Orson Welles, 1975.

Forbidden, The. Dir. Clive Barker, 1978.

Frankenstein. Dir. James Whale, 1931.

Gods and Monsters. Dir. Bill Condon, 1998.

Halloween. Dir. John Carpenter, 1978.

Hellbound: Hellraiser II. Dir. Tony Randel, 1988.

Hellraiser. Dir. Clive Barker, 1987.

Hellraiser: Bloodline. Dir. Kevin Yagher (as Alan Smithee), 1996. 
Hellraiser: Deader. Dir. Rick Bota, 2005.

Hellraiser III: Hell on Earth. Dir. Anthony Hickox, 1992.

House of 1000 Corpses. Dir. Rob Zombie, 2003.

Is Spiritualism a Fraud? Dir. Robert Paul, 1906.

Jurassic Park. Dir. Steven Spielberg, 1993.

Leviathan: The Story of Hellraiser and Hellbound: Hellraiser II. Dir. Kevin McDonagh, 2015.

Lord of Illusions. Dir. Clive Barker, 1995.

The Magnificent Ambersons. Dir. Orson Welles, 1942.

Man With A Movie Camera. Dir. Dziga Vertov, 1929.

Masters of Horror. Showtime. 2005-7.

The Midnight Meat Train. Dir. Ryuhei Kitamura, 2008.

Nightbreed. Dir. Clive Barker, 1990.

Open to Question. BBC, 1984-94.

Philadelphia. Dir. Jonathan Demme, 1993.

Pinocchio. Dirs. Ben Sharpsteen, Hamilton Luske et al. 1940.

The Plague. Dir. Hal Masonberg, 2006.

Rawhead Rex. Dir. George Pavlou, 1986.

The Rocky Horror Picture Show. Dir. Jim Sharman, 1975.

Saint Sinner. Dir. Joshua Butler, 2002.

Salomé. Dir. Clive Barker, 1973.

Saw. Dir. James Wan, 2004.

Saw III. Dir. Darren Lynn Bousman, 2006.

The Silence of the Lambs. Dir. Jonathan Demme, 1991.

Sleepy Hollow. Dir. Tim Burton, 1999.

Spitting Image, ITV, 1984-86.

Tales from the Crypt. HBO, 1989-96.

Tales from the Darkside. CBS, 1983-88.

Underworld. Dir. George Pavlou, 1985.

Videodrome. Dir. David Cronenberg, 1983.

The X-Files. 20th Century Fox Television, 1993-2004.

\section{Internet sources}

Anonymous. 'Clive Barker: AOL Appearance.' Transcript. AOL. 16 July 1996. Revelations: The Official Clive Barker Website. www.clivebarker.com/html/visions/confess/nonls/ cb71696.html. Date accessed: 30 May 2012.

Anonymous. 'Clive Barker: Banking on Blood'. Locus. Vol. 19:7. Issue 306 (July 1986), reproduced in www.clivebarker.info/ints86.html. Date accessed: 12 April 2015.

Anonymous. 'Clive Barker's Freakz.' Press Release. Universal Studios, October 1998. Revelations: The Official Clive Barker Website. www.clivebarker.info/halloweenhorror.html. Date accessed: 2 June 2012.

Anonymous. 'Clive on the Midnight Meat Train.' Reprinted on Revelations: The Official Clive Barker Website. www.clivebarker.info/mmt.html. Date accessed: 10 June 2011. 
Anonymous. 'Halloween Horror Nights III.' Universal Studios Press Release, 1999. Reprinted on Revelations: The Official Clive Barker Website. www.clivebarker.info/ halloweenhorror.html. Date accessed: 2 June 2012.

Barker, Clive. 'Edgar Allan Poe.' Independent magazine. 30 November 1991. Revelations: The Official Clive Barker Website. www.clivebarker.info/essaysb.html. Date accessed: 30 July 2012.

Barker, Clive. 'News - Clive Wants To Save Midnight Meat Train!' Revelations: The Official Clive Barker Website. www.clivebarker.info/newssavemmt.html. Date accessed: 2 June 2012.

Barker, Clive. 'Interview with Larry King. Larry King Live.' CNN. 6 May 1987. Transcript rpt. on Revelations: The Official Clive Barker Website. www.clivebarker.info/ints87.html. Date accessed: 2 June 2012.

Barker, Clive. Interview. 'Clive from New York' Spawn.Com, 13 February 2001, www.spawn.com/news/news.aspx?id=5174. Date accessed: 7 June 2014.

Barker, Clive. Interviewed by Madeline Puckett at Fangoria Weekend of Horrors, 20 May 2007. Revelations: The Official Clive Barker Website. www.clivebarker.info/ mbgbarker.html. Date accessed: 7 June 2014.

Barker, Clive. 'Interviews 1990: Part One.' Revelations: The Official Clive Barker Website. www.clivebarker.info/ints90.html. Date accessed: 25 June 2012.

Barker, Clive. Interviewed by Lucy A. Sneider. 'It's All Part of the Fun.' Revelations: The Official Clive Barker Website. www.clivebarker.info/mbgbarker.html. Date accessed: 7 June 2014.

Barker, Clive. Interviews on 'Lord of Illusions.' Revelations: The Official Clive Barker Website. www.clivebarker.info/lordofillusions.html. Date accessed: 28 June 2012.

Barker, Clive. Interviews on 'Nightbreed. Revelations: The Official Clive Barker Website. www.clivebarker.info/nightbreed.html. Date accessed: 24 June 2012.

Barker, Clive. Interviewed on Open to Question. 8 December 1987. BBC Two. www.youtube.com/watch?v=ZOqKgrbjfQ. Date accessed: 15 December 2015.

Beeler, Michael. 'Lord of Illusions - Filming the Books of Blood.' Cinefantastique. Vol. 26:3. 1995. Revelations: The Official Clive Barker Website. www.clivebarker.info/ ints95b.html. Date accessed: 4 June 2012.

Bohling, James. 'Dreaming of a Nightmare.' Frontiers, 27 October 2000. Revelations: The Official Clive Barker Website. www.clivebarker.info/coldheartbarker.html. Date accessed: 10 January 2016.

Cherry, Brigid. 'Gothics and Grand Guignols: Violence and the Gendered Aesthetics of Cinematic Horror'. Participations: International Journal of Audience Research. Vol 5:1 (May 2008). www.participations.org/Volume\%205/Issue\%201\%20-\%20special/5_01 _cherry.htm.

Cooper, Dennis. 'Fuck the Canon.' LA Weekly. 31 August-6 September 2001. Literary Supplement. Reprinted on Revelations: The Official Clive Barker Website. www .clivebarker.info/halloweenhorror.html. Date accessed: 2 June 2012.

Ebert, Roger. Rev. of Hellbound: Hellraiser II. 23 December 1988. Roger Ebert Online Archive. www.rogerebert.com/reviews/hellbound-hellraiser-ii-1988. Date accessed: 15 January 2016.

Ebert, Roger. Rev. of Hellraiser. 18 September 1987. Roger Ebert Online Archive. www.rogerebert.com/reviews/hellraiser-1987. Date accessed: 15 January 2016. 
French, Philip, 'The Firm.' Observer (20 September 2009). https://www.theguardian.com/ film/2009/sep/20/the-firm-film-review. Date accessed: 24 April 2009.

Garcia, Irene. 'The Horror!' LA Times. 15 October 1998. Revelations: The Official Clive Barker Website. www.clivebarker.info/halloweenhorror.html. Date accessed: 28 May 2012.

Hughes, David. 'High Abuse From the Left, Low Abuse From the Right.' The Telegraph. 16 February 2009. http://blogs.telegraph.co.uk/news/davidhughes/8594817/High_ abuse_from_the_Left_low_abuse_from_the_Right_/. Date accessed: 18 September 2015.

Isaacson, Walter, 'Hunting for the Hidden Killers: AIDS Disease Detectives Face a Never Ending Quest', Newsweek (122) 1, 4 July 1983. http://content.time.com/time/ magazine/0,9263,7601830704,00.html. Date accessed: 18 September 2015.

Jenkins, Simon. 'This Icon of 60s New Brutalism Has its Champions. So Let Them Restore It.' Guardian, 20 June 2008. https://www.theguardian.com/commentisfree/2008/ jun/20/architecture. Date accessed: 26 April 2015.

Jones, Anderson. 'Movie Scoop.' Yahoo Entertainment. 11 October 2002. Revelations: The Official Clive Barker Website. www.clivebarker.info/ints02b.html. Date accessed: 2 June 2012.

Lowman, Rob. 'Freakz Alive, Clive! His "Living Movie” an A-Maze-ing Experience.' Daily News (14 October 1998). Revelations: The Official Clive Barker Website. www.clivebarker.info/halloweenhorror.html. Date accessed: 2 June 2012.

McDonald, B. 'Knott's Berry Farm Unveils Halloween Haunt 2014 Mazes.' LA Times. 8 August 2014. www.latimes.com/travel/themeparks/la-trb-halloween-haunt-2014-knotts -berry-farm-20140807-story.html. Date accessed: 1 April 2015.

Miéville, China. 'Candy and Carrion' Rev. of Abarat by Clive Barker. Guardian. 19 October 2002. www.theguardian.com/books/2002/oct/19/sciencefictionfantasyandhorror .clivebarker. Date accessed: 1 March 2016.

Moorcock, Michael. 'Epic Pooh.' Revised edition. Revolution Science Fiction. www.revolutionsf .com/article.php?id=953. Date accessed: 30 July 2012.

Murder, Mike. 'Clive Barker's Harvest'. Horror Night Nightmares. www.horrornightnightmares .com/forums/index.php/topic/2664-clive-barkers-harvest/. Date accessed: 12 April 2015.

Nelson, Andrew. 'Cinema From Attractions: Story and Synergy in Disney's Theme Park Movies.' Cinephile: The University of British Columbia's Film Journal, 4 (2008). www.cinephile.ca/archives/volume-4-post-genre/cinema-from-attractions-story-andsynergy-in-disney\%E2\%80\%99s-theme-park-movies/. Date accessed: 2 April 2012.

Newman, Kim. 'Clive Barker.' Interzone. No 14. Winter (1985/86). www.clivebarker.info/ damnatbarker.html. Date accessed: 9 January 2016.

Nutman, Philip. 'Birth of the Nightbreed.' Fangoria. No. 86 (1989). Revelations: The Official Clive Barker Website. www.clivebarker.info/nightbreed.html. Date accessed: 4 June 2012.

Peterson, Evan J. 'The Company of Monsters: An Interview with Clive Barker.' The Southeast Review. Vol. 26:2, 2008. Revelations: The Official Clive Barker Website. www.clivebarker.info/scarletbarker.html. Date accessed: 9 January 2016.

Poe, Edgar Allan. 'The Philosophy of Composition.' 'The Raven' and the Philosophy of Composition. San Francisco and New York: Paul Elder \& Company, 1907. Archive. 
org. https://archive.org/details/ravenandphilosop00poeerich. Date accessed: 27 July 2012.

Pouncey, E. 'Barker Psychosis'. New Musical Express. 13 February 1993. Revelations: The Official Clive Barker Website. www.clivebarker.info/ints93.html. Date accessed: 2 June 2012.

Ruby, Smilin' Jack. 'Clive Barker's Busy, Busy, Busy Year.' 13th Street. 13 July 2001. Revelations: The Official Clive Barker Website. www.clivebarker.info/ints01b.html. Date accessed: 2 June 2012.

Shaw, Daniel. 'A Humean Definition of Horror' Film-Philosophy. Vol. 1:4 (1997). www.filmphilosophy.com/vol1-1997/n4shaw.

Stokes, Phil and Sarah Stokes. 'A Spiritual Retreat: The Seventeenth Revelatory Interview.' Revelations: The Official Clive Barker Website. 26 March, 2007. www.clivebarker.info/ intsrevel17.html. Date accessed: 14 January 2016.

Stokes, Phil and Sarah Stokes. 'Hellfire and the Demonation. Revelations: The Official Clive Barker Website. www.clivebarker.info/intsrevel19.html. Date accessed: 2 June 2012.

Stokes, Phil and Sarah Stokes. 'Universal's Halloween Horror Nights.' Revelations: The Official Clive Barker Website. 7 September 2007. www.clivebarker.info/ halloweenhorror.html. Date accessed: 12 April 2015.

Tucker, Ken. 'One Universe at a Time Please.' Rev. of The Great and Secret Show by Clive Barker. New York Times Book Review. 11 February 1990. www.nytimes.com/1990/02/11/ books/one-universe-at-a-time-please.html. Date accessed: 14 January 2016.

Turek, Ryan. 'Facing the Beast: On the Set of Clive Barker's Dread.' October 2008. http:// shocktillyoudrop.com/news/topnews.php?id=12919. Date accessed: 8 June 2011.

Twelker, Eric. 'Crossing Over'. Amazon. January 2001. Revelations: The Official Clive Barker Website. www.clivebarker.info/undying.html. Date accessed: 2 June 2012.

Variety Staff. Rev of Hellbound: Hellraiser II. Variety. 31 December 1987. http:// variety.com/1987/film/reviews/hellbound-hellraiser-ii-1200427565/. Date accessed: 15 January 2016.

\section{Video games}

Clive Barker's Jericho. MercurySteam. 2007. Codemasters.

Clive Barker's Undying. DreamWorks Interactive. 2001. EA Games. 